\title{
Engineers for the Future
}

\author{
Dr. Ishrat Meera Mirzana ${ }^{1}$, Mr. Rajeev Lal ${ }^{2}$ \\ ${ }^{1}$ Professor, Mechanical Engg. Dept., Muffakham Jah College of Engg. \& Tech., Hyderabad. \\ ${ }^{2}$ Director, EWB-India. \\ 1ishrat.mirzana@gmail.com \\ ${ }^{2}$ rajeev.1@ hotmail.com
}

\begin{abstract}
The present paper discusses about the transformation that has been observed in the engineering students being associated with Engineers Without Borders (EWB). The paper presents how inter and intra personal skills have developed in the budding engineers while practically executing the socio-responsive projects that has benefitted the local community. The paper describes how the experiential learning can transform the personality of the students and help them in having better future/ career in their further life.
\end{abstract}

Keywords: Socio-responsive projects, experiential learning, transform.

\section{Introduction}

Rapid developments in the use of Artificial intelligence and Machine learning are leading to automation that impacts a number of blue collar and white collar jobs. In the years to come, as the Fourth Industrial Revolution progresses, a number of technical and regular tasks will get automated and the skills required for success and growth will change.

A study by the Everest Group in 2018 [1] among global enterprises brought out that critical skills needed for their success in future include intuition, innovation, design thinking, problem solving and leadership. These skills will be important and essential for engineers working in these enterprises too. Other skills the other hand our engineering education is oriented towards theoretical classroom teaching. Engineering students need opportunities and ways to develop the soft skills required for success in future.

My experience at Mufakkam Jah College of Engineering and Technology (MJCET), Hyderabad, India has shown that participation by students in the projects promoted by Engineers Without Borders - India [2] with focus towards the weaker sections of society enables them to develop the skills required for future and for success in their profession. There is noticeable transformation in the personalities and behaviour of the participating students. Such Project Based Learning is a good and effective way to inculcate many of the needed skills in students.

\section{Corresponding Author}

Dr. Ishrat Meera Mirzana, Professor, MED, MJCET.

This paper presents some actual case studies to confirm our experience. Profiles of some students who took leadership role in EWB-India Student Chapter as Presidents of the Chapter, their efforts for its growth and in its activities have been included in the paper to highlight the transformation that was seen in them. Students who took the lead got benefitted in multiple ways.

\section{Methodology adopted for transformation}

It was realised that the knowledge gained in engineering education itself will not help the students to understand the community requirements and the real meaning of engineering i.e., problem solving. Thus, as a faculty we realised the importance of service learning and we started the student chapter of Engineers without Borders.

Thus, as a part of accomplishing the task/aim, we imbibed the habit of helping the less privileged community by asking the students to contribute the resources available with them that they think is no longer useful for them. This process helped us in evaluating the personality of the students and realizing who are having the real zeal to make a difference to the society and the students too, realize in this process, how they can utilize the resources and understand the concepts of optimization for the real time problems.

The next stage that we follow is data collection methodology. This will help the student in understand the process of synthesis and analysis. In this process, we ask the student to define a problem and accordingly prepare a plan for the same for providing the solution and the various possible strategies for acquiring the solution. In this process, students learn the traits of problem identification, problem definition and synthesis and above all the proper project report preparation.

The third and final stage followed for the transformation of the students is experiential learning and self-learning process. Here, the students are subjected to carry out the activity/ task/ community project based on the requirements of the local community where the activity/ project has to be executed. 
This process is monitored and guided by the faculty advisor and student coordinator of the chapter. The present paper objective is to present how being a part of EWB and its projects helped them transform into professional engineers and/or industry ready engineers. The paper presented the transformation of only the students who held the position of the President of the EWB-MJCET student chapter though there has been significant change in all the students who were/are ewbians of MJCET.

\section{Personality transformation and traits acquired}

\subsection{Inspirational Leadership and recognition in US Universities}

In the academic year 2010-11, a production engineering student who was from middle class family became the president of MJCET EWB-India Student Chapter. He was in 3rd year of his engineering course. As there was very little awareness among the students to be part of such associations and that too chapter for a NGO, he had to convince students a lot to become members. He started off by conducting EWB week wherein the focus was on environment awareness, societal problems etc. At the end of his term as President, he shared his personal experience in holding that office. He said that the position helped him in learning how to convince people, be it management or his fellow students for execution of service learning activities and projects, and how to plan activities with an objective in mind and execute them in a timely fashion. The role helped in developing his inter and intra personal skills, and in realizing the importance and practice of time management. His association with EWB was given weightage during the admission process for US universities. He secured admission and went to US for higher studies.

\subsection{Charisma and Placement through Campus Recruitment}

In 2012-13, a girl was elected as a president of the Student Chapter for the first time. Her success was noticed in the institution. She managed the Student Chapter Executive committee and also the activities well. During this period, we started off our collaborative projects with Pratt and Whitney, USA. This collaboration was carried out under the guidance of (Late) Dr. Aliuddin Ansari, founder of EWBIndia, on seeing the efforts made by the cabinet led by a girl president. This also marked our beginning in doing socioresponsive projects as envisioned by EWB. Though she was not an outstanding student in her academics, she could suffice her personality by transforming herself through the self-learning practices she was exposed in her term as a president of EWB-MJCET student chapter. She transformed herself as a person with charisma who with her team did the best in any assigned task. The capabilities that she gained through EWB-India activities and projects helped her get a good placement during campus recruitment.

\subsection{Innovation and Design Thinking}

In 2012-13, an enthusiastic student who had a great zeal to make difference to his local community was elected as president through the election process, which we follow every year as per the guidelines of EWB-India. He developed a great fan following among his production engineering batch mates. He worked with Dr. Aliuddin Ansari on Reuse-Redirect project. Along with his team he worked on development projects at the Krushi Home, which provides shelter and educational opportunities to children found on the streets. He started the cloth and paper collection drive activities in the Chapter. Items collected in this drive contribute to supporting the Nachiket Tapovan Orphanage. He proved himself as one the best presidents of the Student Chapter so far. He made a mark for himself and in EWBIndia too. He developed and honed management skills during the execution of projects and while coordinating the efforts of fellow students from different engineering streams. This was possibly the reason that he chose to pursue MBA course after his graduation at MJCET. Two years of his association with EWB-MJCET student chapter helped him transform himself so much that he could clearly define goals in his life and understand the concept that we grow when our society/neighbourhood is taken care of.

\subsection{Problem Solving}

In 2013-14, a student who was the only son of working parents was elected as president. He had a challenge to prove himself much better than his predecessor. So, he started motivating students to be part of EWB projects and during his period the future president of EWB too joined EWB MJCET student chapter as member from second year of engineering. To attract the students and to motivate them he used to display fun activities/projects like cyclopump, wherein power can be generated etc. through exercise and to make the students understand how the energy transforms itself into different forms. He focused on doing sustainable projects and come up with simple solutions for the problems along with his team. One of the projects was solar fan for traffic police. Unfortunately, during this process, his academics took back seat and he landed up with backlogs and could not complete his graduation in 4 yrs. It took him 6 more months to clear off all his subjects. He wanted to learn more about unconventional energy sources and his major project was also on waste heat recovery system. After completing his graduation, he applied for higher studies and he was glad to see a positive response from Universities seeing his profile and association with EWB. He was on cloud nine especially in student visa interview he was questioned about EWB projects and was granted visa. The loss of 6 months was more than compensated by the benefit he got from the work he did in EWB-India Student Chapter. It is an achievement for us too as we knew that he had 
contributed his time for EWB and we wanted best to happen to him too. That's why they say that when you do good, it will come back in one or the other form.

\subsection{Exploring new Horizons}

For 2014-15 and 2015-16, a studious and bright student was elected as president. As he was associated with EWB since his second year. He did strategic planning to take EWB MJCET chapter to the next level. So, with the money that was being saved from student membership and an industrial visit, we could collect an amount of Rs.18000/- . With that amount we thought of synergizing all our projects at one target. So, we adopted Erramanzil government school nearby and did plumbing works, painting of school boards, levelling of school ground etc., all these activities were accomplished by a team of 50 student members in 15 days. We felt very glad at this achievement. This was a mile stone in initiating collaborative projects.

In his second term, we planned to start conducting EWB conference on Technologies for Sustainable Ecosystem (TSE). As usual though we had an idea, we did not have the funding to implement it. So, he prepared a profile of EWB Chapter and its projects and started approaching the corporates for sponsorship and it was the first time we got a sponsorship funding of Rs.30,000/-. With the support of Dr. Ashok Agarwal, we could pool in speakers for the EWB conference and we could conduct the conference. The papers covered projects wherein sustainable projects were either executed or the concept development of the same was defined. To have knowledge transfer with the other universities too and so, we got into MOU with UCONN university, USA. He was a prompt and very well organized person. He often used to say that he developed his skills by being with EWB and working in close association with Dr. Ashok Agarwal.

He thought it's time to have a separate office for EWB Chapter as we had made our presence felt in EWB-India with our projects. So we started the construction of EWB MJCET activity center as an E-learning center hub and also our office and we got tremendously support morally and financially from EWB-MJCET and Sultan-ul-uloom society. He made an impression on everyone. Though he was a management quota student, only son of upper class family, he had a real zeal to make a difference to the society and wanted to be associated with socio-responsive projects. His parents too were glad and happy to see this personality trait of their son. The project documentation and planning helped him to excel himself in technical side too as he got patents published and also papers published before completion of his graduation.

\subsection{Passion and perseverance}

In 2016-17, a not so well off family background student was elected as president. He was a non-local person and had initial doubts on how he will manage things. But his experience in doing the projects, conducting the annual conference TSE and getting sponsorship from SBI, proved that if you have passion, you can transform yourself. This transformation was made possible by his associating himself with EWB, which provides an international exposure and knowledge transfer. He worked closely with Mr. Bharat Maharaj and worked in establishing different e-learning centers. His experience and exposure helped him in getting a job in Accenture in off-campus placement.

\subsection{Transformation in Personality}

In 2018-19, a timid looking student was elected as president. Being a part of EWB has transformed him from an introvert person to an extrovert person who has learnt the life skills by executing and working on EWB projects.

\section{Conclusion}

Leadership role in EWB-India Student Chapter and Project Based Learning in the social projects provides the opportunity to our students to imbibe the attributes needed for future engineers. They develop and strengthen their soft skills and grow into humanitarian engineers. They develop skills and get benefitted in their higher studies as well as in getting better placement through campus recruitment. The transformation seen in participating students is remarkable. The end result far outweighs the efforts being put in by us for continued success of the EWB-India Student Chapter at MJCET.

The success stories of the students indicate how the experiential learning can enhance the possibilities of students in acquiring directional goals in their life's. The methodology adopted by the faculty is not the strategic planning of flipped classroom or blended teaching but the importance of service learning and seamless integration and correlation with the academic knowledge gained through the curriculum of engineering.

\section{Acknowledgement}

I thank EWB-India and its directors especially Dr. Ashok Agarwal, Director for their continuous support to EWBMJCET student chapter and helping my students to be a part of problem solvers for the society. I also thank all my students about whom I mentioned in my paper.

\section{References:}

[1] Jimit Arora, Ronak Doshi, Aaditya Jain, Pranati Goswami, Supratim Nandi, "Duck Creek Services: Modernization Strategies to Prevent Core Commoditization - Services PEAK Matrix ${ }^{\mathrm{TM}}$ Assessment 2018”, A report by Everest Group, 2018.

[2] www.ewb-india.org 